\title{
AM-37 and ST-36 Are Small Molecule Bombesin Receptor Antagonists
}

\author{
Terry W. Moody ${ }^{1 *}$, Nicole Tashakkori', Samuel A. Mantey ${ }^{2}$, Paola Moreno ${ }^{2}$, \\ Irene Ramos-Alvarez ${ }^{2}$, Marcello Leopoldo ${ }^{3}$ and Robert T. Jensen ${ }^{2}$

\begin{abstract}
'Department of Health and Human Services, National Cancer Institute, Center for Cancer Research, Bethesda, MD, United States, ${ }^{2}$ National Institute of Diabetes, Digestive and Kidney Disease, Digestive Diseases Branch, Bethesda, MD, United States, ${ }^{3}$ Dipartimento di Farmacia, Scienze del Farmaco, Università degli Studi di Bari Aldo Moro, Bari, Italy
\end{abstract}

\section{OPEN ACCESS}

Edited by:

Hubert Vaudry,

University of Rouen, France

Reviewed by:

Miriam Goebel-Stengel,

HELIOS Klinik Zerbst, Germany

Jana Sopkova-de Oliveira Santos,

Centre d'Etudes et de Recherche sur

le Médicament de Normandie (CERMN), France

*Correspondence:

Terry W. Moody

moodyt@mail.nih.gov

Specialty section:

This article was submitted to

Neuroendocrine Science,

a section of the journal

Frontiers in Endocrinology

Received: 30 November 2016

Accepted: 05 July 2017

Published: 21 July 2017

Citation:

Moody TW, Tashakkori N,

Mantey SA, Moreno P, Ramos-

Alvarez I, Leopoldo M and Jensen RT

(2017) AM-37 and ST-36 Are Small

Molecule Bombesin

Receptor Antagonists.

Front. Endocrinol. 8:176.

doi: 10.3389/fendo.2017.00176
While peptide antagonists for the gastrin-releasing peptide receptor $\left(\mathrm{BB}_{2} \mathrm{R}\right)$, neuromedin $B$ receptor $\left(B_{1} R\right)$, and bombesin $(B B)$ receptor subtype-3 (BRS-3) exist, there is a need to develop non-peptide small molecule inhibitors for all three BBR. The BB agonist (BA)1 binds with high affinity to the $B_{1} R, B B_{2} R$, and $B R S-3$. In this communication, small molecule BBR antagonists were evaluated using human lung cancer cells. AM-37 and ST-36 inhibited binding to human $\mathrm{BB}_{1} \mathrm{R}, \mathrm{BB}_{2} \mathrm{R}$, and BRS-3 with similar affinity $(K i=1.4-10.8 \mu M)$. AM-13 and AM-14 were approximately an order of magnitude less potent than AM-37 and ST-36. The ability of BA1 to elevate cytosolic $\mathrm{Ca}^{2+}$ in human lung cancer cells transfected with $\mathrm{BB}_{1} \mathrm{R}, \mathrm{BB}_{2} \mathrm{R}$, and $\mathrm{BRS}-3$ was antagonized by $\mathrm{AM}-37$ and ST-36. BA1 increased tyrosine phosphorylation of the EGFR and ERK in lung cancer cells, which was blocked by AM-37 and ST-36. AM-37 and ST-36 reduced the growth of lung cancer cells that have BBR. The results indicate that AM-37 and ST-36 function as small molecule BB receptor antagonists.

Keywords: small molecule antagonists, GRPR, NMBR, bombesin receptor subtype-3, lung cancer

\section{INTRODUCTION}

The bombesin (BB) family of peptides is biologically active in the central nervous system (CNS) and periphery. BB, a 14 amino acid peptide isolated from frog skin, has 9 of the 10 same C-terminal amino acids as does human gastrin-releasing peptide (GRP), a 27 amino acid peptide (1). GRP binds with high affinity to the $\mathrm{BB}_{2} \mathrm{R}$, which regulates pruritus, lung development, and gastrin secretion. Neuromedin B (NMB) is a 10 amino acid peptide with $70 \%$ sequence homology to the C-terminal of $\mathrm{BB}$. NMB binds with high affinity to the $\mathrm{BB}_{1} \mathrm{R}$ and causes satiety, hypothermia, and thyrotropin (TSH) secretion from the pituitary (2). BB receptor subtype-3 (BRS-3) is an orphan receptor with homology to the $\mathrm{BB}_{1} \mathrm{R}$ and $\mathrm{BB}_{2} \mathrm{R}$, and binds the universal agonist, $\mathrm{BB}$ agonist $(\mathrm{BA}) 1$, with high affinity as does the $B_{1} R$ and $B_{2} R$ (3). Because $B R S-3$ knockout mice have impaired energy balance, glucose homeostasis, and increased body weight, BRS-3 agonists may function as satiety agents (4). In the CNS, GRP and NMB may act in a paracrine manner being released from brain neurons in the hypothalamus and dentate gyrus, respectively, activating $\mathrm{BB}_{2} \mathrm{R}$ and $\mathrm{BB}_{1} \mathrm{R}$ in adjacent cells (5).

In numerous cancers, including lung cancer, GRP and NMB function in an autocrine manner to stimulate cellular proliferation. Small cell lung cancer (SCLC), a neuroendocrine tumor, has high levels of GRP $(6,7)$. GRP is secreted from SCLC and binds to cell surface $\mathrm{BB}_{2} \mathrm{R}$ resulting in increased cellular proliferation (8). NMB is present in both SCLC and non-small cell lung cancer (NSCLC) cells, and after secretion it binds to cell surface $\mathrm{BB}_{1} \mathrm{R}$ stimulating proliferation (9). Because 
many lung cancer cells have $\mathrm{BB}_{1} \mathrm{R}, \mathrm{BB}_{2} \mathrm{R}$, and/or BRS-3 there is a need to develop antagonists that block all three receptors of the BB family.

The human $\mathrm{BB}_{1} \mathrm{R}, \mathrm{BB}_{2} \mathrm{R}$, and $\mathrm{BRS}-3$ contain 390,384 , and 399 amino acids and have approximately $50 \%$ sequence homology. The $B_{1} R, B_{2} R$, and BRS- 3 are members of the rhodopsin $\beta$ group $\mathrm{G}$ protein-coupled receptors (GPCR) family, and they interact with $\mathrm{Gq}$ causing phosphatidylinositol (PI) turnover (10). PI-4,5-bisphosphate $\left(\mathrm{PIP}_{2}\right)$ is metabolized to diacylglycerol, which activates protein kinase $\mathrm{C}$ and inositol-trisphosphate $\left(\mathrm{IP}_{3}\right)$ which causes elevated cytosolic $\mathrm{Ca}^{2+}$. Neuropeptide receptors regulate the transactivation of the epidermal growth factor (EGF) receptor leading to NSCLC proliferation (11). The proliferation of NSCLC cells caused by BA1 can be inhibited by the tyrosine kinase inhibitor (TKI) gefitinib or BBR antagonists. The actions of $\mathrm{BA} 1$ on $\mathrm{BB}_{1} \mathrm{R}, \mathrm{BB}_{2} \mathrm{R}$, and BRS-3 are antagonized selectively by PD168368, PD176252, and Bantag-1, respectively (12).

In the present study, small molecules were synthesized and their ability to antagonize $\mathrm{BB}_{1} \mathrm{R}, \mathrm{BB}_{2} \mathrm{R}$, and $\mathrm{BRS}-3$ in lung cancer cells evaluated. The results indicate that AM-37 and ST-36 are useful agents to inhibit the growth of NSCLC cells which have $\mathrm{BB}_{1} \mathrm{R}, \mathrm{BB}_{2} \mathrm{R}$, or BRS-3.

\section{MATERIALS AND METHODS}

\section{Cell Culture}

Non-small cell lung cancer cell line NCI-H1299 (ATCC, Manassas, VA, USA) was stably transfected with $\mathrm{BB}_{1} \mathrm{R}, \mathrm{BB}_{2} \mathrm{R}$, and BRS-3. The transfected cells were grown in RPMI-1640 containing $10 \%$ fetal bovine serum (FBS) with $0.3 \mathrm{mg} / \mathrm{ml}$ geneticin (Invitrogen, Grand Island, NY, USA). The transfected cells, which contained approximately 100,000 receptors/cell, were weekly split using trypsin/EDTA (13). In addition, lung cancer cell lines NCI-H727, H1299, and H1975 were purchased from ATCC and cultured in RPMI-1640, which contained 10\% FBS. The cell types were derived from different human biopsy specimens. These studies were approved by the NIDDK biospecimens and biosafety committees.

\section{Ligand Synthesis}

The small molecules were synthesized as described previously (14). Figure 1D shows the structural formula of AM-37, (R)-3-(1Hindol-3-yl)-2-[3-(4-methoxyphenyl)ureido]-N-[[1-(3-pyridinyl) cyclohexyl]methyl]propanamide, and of its S-enantiomer ST-36. Figure 1E shows the structural formula of AM-13, (R)-N-[[1(4-fluorophenyl)cyclohexyl]methyl]-3-(1H-indol-3-yl)-2-[3(4-methoxyphenyl)ureido]propanamide, and its S-enantiomer AM-14. The molecular weight of AM-37 and ST-36 is $525.6 \mathrm{Da}$, whereas the molecular weight of AM-13 and AM-14 is $542.2 \mathrm{Da}$.

\section{Receptor Binding}

The ability of AM-37, ST-36, AM-13, and AM-14 to inhibit specific ${ }^{125} \mathrm{I}-\mathrm{BA} 1$ binding to NSCLC cells transfected stably with $\mathrm{BB}_{1} \mathrm{R}, \mathrm{BB}_{2} \mathrm{R}$, and $\mathrm{BRS}-3$ was investigated. NSCLC cells were placed in 24 well plates. When confluent, the cells were washed three times with PBS. The cells were incubated with binding buffer (PBS containing $0.25 \%$ bovine serum albumin and $0.025 \%$ bacitracin, Sigma-Aldrich, St. Louis, MO, USA). Various concentrations of AM-37, ST-36, AM-13, or AM-14 were added to the cells for $10 \mathrm{~min}$, followed by $100,000 \mathrm{cpm}$ of ${ }^{125} \mathrm{I}$-BA1 $(0.16 \mathrm{nM})$ and incubated at $37^{\circ} \mathrm{C}$ for $30 \mathrm{~min}$ when equilibrium of binding was reached. The cells were rinsed three times with binding buffer for $2 \mathrm{~min}$ at $4^{\circ} \mathrm{C}$. The cells that contained bound peptide dissolved in $0.2 \mathrm{~N} \mathrm{NaOH}$ and counted in a Wallac $1470 \gamma$-counter. The $K_{\mathrm{i}}$ was calculated as described (15).

\section{Cytosolic $\mathrm{Ca}^{2+}$}

The ability of AM-37, ST-36, AM-13, and AM-14 to function as $\mathrm{BBR}$ antagonists was investigated. NSCLC cells transfected with $B_{1} R, B_{2} R$, and $B R S-3$ were harvested and loaded with Fura-2AM (Calbiochem, La Jolla, CA, USA) as described previously (16). The excitation ratio was determined at 340 and $380 \mathrm{~nm}$ with an emission wavelength of $510 \mathrm{~nm}$. The lung cancer cellular calcium response was determined after the addition of AM-37, ST-36, AM-13, or AM-14 followed by $10 \mathrm{nM}$ BA1.

\section{Tyrosine Phosphorylation}

The tyrosine phosphorylation of the EGFR and ERK was investigated by western blot. NSCLC cells transfected with $B B_{1} R, B_{2} R$, and BRS-3 were placed in $10 \mathrm{~cm}$ dishes. When the cells were confluent, they were placed in SIT medium (RPMI-1640 containing $3 \times 10^{-8} \mathrm{M}$ sodium selenite, $5 \mu \mathrm{g} / \mathrm{ml}$ bovine insulin, and $10 \mu \mathrm{g} / \mathrm{ml}$ apo-transferrin; Sigma-Aldrich, St. Louis, MO, USA) for $3 \mathrm{~h}$. AM-37, ST-36, AM-13, or AM-14 were added for $30 \mathrm{~min}$ followed by $100 \mathrm{nM}$ BA1 for $2 \mathrm{~min}$. Cell extracts were made as described previously (16), and $600 \mu \mathrm{g}$ of protein extract was immunoprecipitated with $4 \mu \mathrm{g}$ anti-phosphotyrosine antibody (Becton Dickenson, USA). The immunoprecipitates were fractionated using a 4-20\% polyacrylamide gel (Novex, San Diego, CA, USA). Proteins were transferred to a nitrocellulose membrane and incubated with $2 \mu \mathrm{g}$ anti-EGFR or anti-ERK antibody (Cell Signaling Technologies, Danvers, MA, USA). After washing the blot, it was incubated with enhanced chemiluminescence detection reagent (Thermo Scientific) for $5 \mathrm{~min}$ and exposed to Biomax XAR film (Carestream, Rochester, NY, USA). The band intensity was determined using a Kodak image station 440 densitometer. Alternatively, $20 \mu \mathrm{g}$ of protein extract was loaded onto polyacrylamide gels and after transfer to nitrocellulose, the blot was probed with anti-PY ${ }^{1,068}$-EGFR, anti-EGFR, anti-PY ${ }^{204} \mathrm{ERK}$, or anti-ERK (Cell Signaling Technologies, Danvers, MA, USA).

\section{Proliferation}

The proliferation of NSCLC cells was investigated using the 3-(4,5-demethylthiazol-2-yl)-2,3-diphenyl-2H-tetrazolium bromide (MTT) assay as described previously (16). NCI-H727, H1299, and H1975 cells were placed in SIT medium and varying concentration of AM-37, ST-36, AM-13, or AM-14 added. After 2 days, $0.1 \%$ MTT solution $(15 \mu \mathrm{l})$ was added. After $4 \mathrm{~h}$, DMSO $(150 \mu \mathrm{l})$ was added and the absorbance at $570 \mathrm{~nm}$ was determined.

\section{Statistical Analysis}

The results are expressed as the mean \pm SD. Statistical significance of differences was performed by a one-way or two-way 

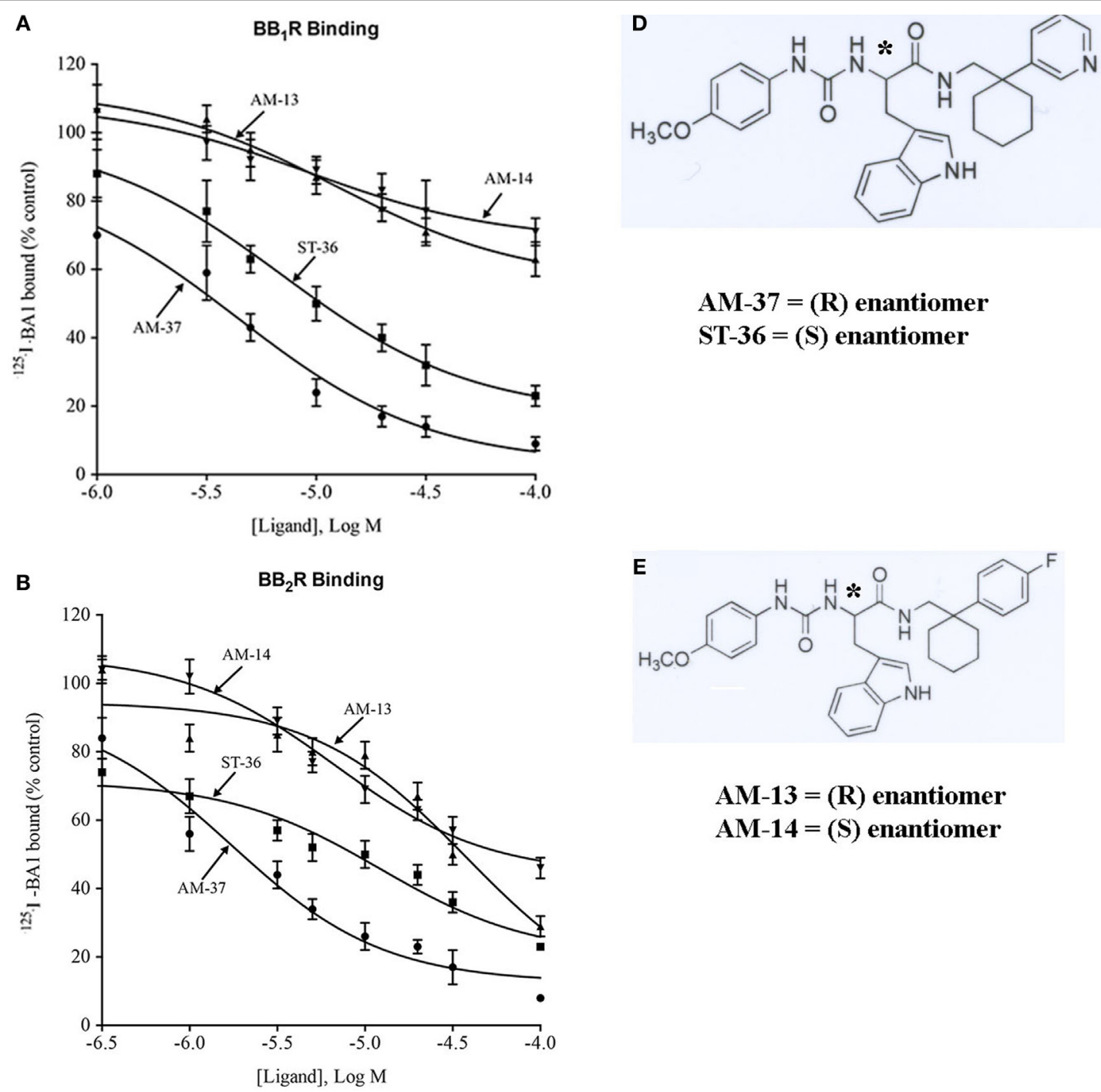

\section{$\mathrm{AM}-37=(\mathbf{R})$ enantiomer \\ ST-36 $=(S)$ enantiomer}

\section{AM-13 $=(\mathbf{R})$ enantiomer \\ AM-14 = (S) enantiomer}

C

BRS-3 Binding

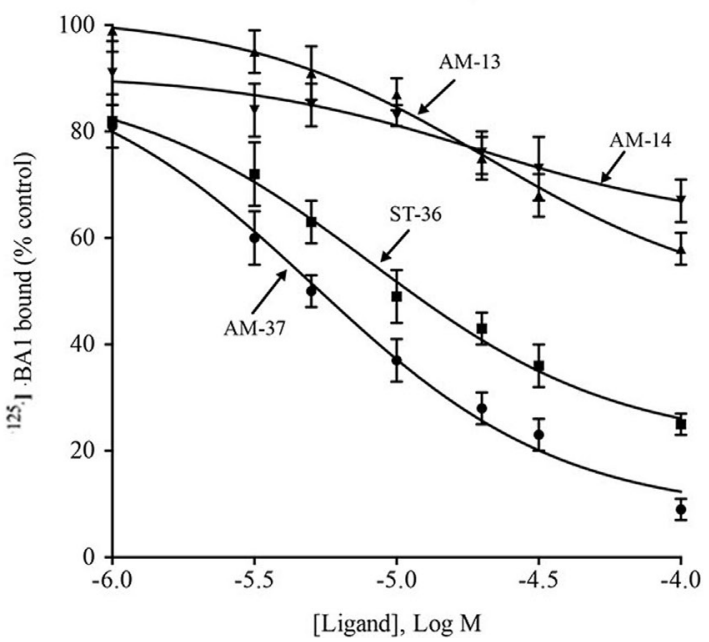

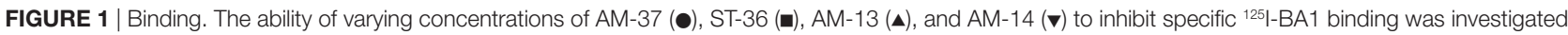
using (A) $\mathrm{BB}_{1} \mathrm{R}-$-, (B) $\mathrm{BB}_{2} \mathrm{R}-$, and (C) BRS-3-transfected NCl-H1299 cells. The mean value $\pm \mathrm{SD}$ of three determinations each repeated in duplicate is shown. (D) The structure of AM-37 and ST-36 is shown. (E) The structure of AM-13 and AM-14 is shown; *indicates the optically active site. 
repeated measures of variance. The binding curves were drawn using PRISM.

\section{RESULTS}

\section{Receptor Binding}

The ability of the small molecules to bind to $\mathrm{BB}_{1} \mathrm{R}, \mathrm{BB}_{2} \mathrm{R}$, and BRS-3 was investigated. AM-37 (R-enantiomer) inhibited specific ${ }^{125} \mathrm{I}-\mathrm{BA} 1$ binding to $\mathrm{BB}_{1} \mathrm{R}, \mathrm{BB}_{2} \mathrm{R}$, and $\mathrm{BRS}-3$ in a dose-dependent manner with $K_{\mathrm{i}}$ values $3.6,1.4$, and $5.5 \mu \mathrm{M}$, respectively (Figure 1). ST-36 (S-enantiomer) inhibited specific ${ }^{125} \mathrm{I}-\mathrm{BA} 1$ binding to $\mathrm{BB}_{1} \mathrm{R}, \mathrm{BB}_{2} \mathrm{R}$, and $\mathrm{BRS}-3$ with $K$ i values of 7.9 , 6.9 , and $10.8 \mu \mathrm{M}$, respectively (Figure 1). In contrast, AM-13 (R-enantiomer) and AM-14 (S-enantiomer) inhibited specific ${ }^{125} \mathrm{I}-\mathrm{BA} 1$ binding to $\mathrm{BB}_{1} \mathrm{R}, \mathrm{BB}_{2} \mathrm{R}$, and BRS-3 with $K_{\mathrm{i}}>20 \mu \mathrm{M}$. The results indicate that AM-37and ST-36 bind to $B_{1} R, B_{2} R$, and BRS-3 with greater affinity than does AM-13 and AM-14.

The specificity of binding was investigated. Table 1 shows that BA1 bound with high affinity $\left(K_{\mathrm{i}}=0.002,0.0005\right.$, and $0.004 \mu \mathrm{M})$ to $\mathrm{BB}_{1} \mathrm{R}, \mathrm{BB}_{2} \mathrm{R}$, and BRS-3. AM-37, ST-36, AM-13, and AM-14 inhibited specific ${ }^{125} \mathrm{I}-\mathrm{BA} 1$ binding $\left(K_{\mathrm{i}}=1.4,6.9\right.$, 27 , and $45 \mu \mathrm{M})$ to $\mathrm{BB}_{2} \mathrm{R}$. ST-36 inhibited specific ${ }^{125}$ I-BA1 binding $\left(K_{\mathrm{i}}=7.9\right.$ and $\left.10.8 \mu \mathrm{M}\right)$ to $\mathrm{BB}_{1} \mathrm{R}$ and $\mathrm{BRS}-3$, respectively. AM-13 and AM-14 bind with low affinity to $\mathrm{BB}_{1} \mathrm{R}$ and BRS-3 $\left(K_{\mathrm{i}}>100 \mu \mathrm{M}\right.$ and $>100 \mu \mathrm{M}$, respectively).

\section{Cytosolic $\mathrm{Ca}^{2+}$}

The ability of the small molecules to function as $B_{1} R, B_{2} R$, and BRS-3 antagonists was investigated. Addition of $10 \mathrm{nM}$ BA1 to NCI-H1299 cells transfected with $\mathrm{BB}_{1} \mathrm{R}$ increased the cytosolic $\mathrm{Ca}^{2+}$ from 160 to $178 \mathrm{nM}$ within seconds (Figure 2A). The response was transient and returned to baseline after $1 \mathrm{~min}$. Addition of $30 \mu \mathrm{M}$ AM-37 to NCI-H1299 cells transfected with $\mathrm{BB}_{1} \mathrm{R}$ had no effect on the basal cytosolic $\mathrm{Ca}^{2+}$ but blocked the increase in cytosolic $\mathrm{Ca}^{2+}$ caused by BA1 (Figure 2B). Addition of $30 \mu \mathrm{M}$ AM-14 had no effect of basal cytosolic $\mathrm{Ca}^{2+}$ but partially blocked the increase caused by $10 \mathrm{nM}$ BA1 (Figure 2C). Table 2 shows that AM-37 and AM-14 significantly inhibited the ability of BA1 to increase cytosolic $\mathrm{Ca}^{2+}$ after addition to NCI$\mathrm{H} 1299$ cells transfected with $\mathrm{BB}_{1} \mathrm{R}$. Addition of $10 \mathrm{nM}$ BA1 to NCI-H1299 cells transfected with $\mathrm{BB}_{2} \mathrm{R}$ increased the cytosolic $\mathrm{Ca}^{2+}$ from 160 to $186 \mathrm{nM}$ (Figure 2D). Addition of $30 \mu \mathrm{M}$ ST-36

TABLE 1 | Binding to lung cancer cells transfected with human bombesin receptors.

\begin{tabular}{lccc}
\hline Ligand & \multicolumn{3}{c}{$\boldsymbol{K}_{\mathbf{i}, \boldsymbol{\mu} \mathbf{M}}$} \\
\cline { 2 - 4 } & $\mathbf{B B}_{\mathbf{1}} \mathbf{R}$ & $\mathbf{B B}_{\mathbf{2}} \mathbf{R}$ & $\mathbf{B R S}-\mathbf{3}$ \\
\hline BA1 & $0.002 \pm 0.0002$ & $0.0005 \pm 0.0001$ & $0.004 \pm 0.0003$ \\
AM-37 & $3.6 \pm 0.5$ & $1.4 \pm 0.2$ & $5.5 \pm 0.6$ \\
ST-36 & $7.9 \pm 0.9$ & $6.9 \pm 0.3$ & $10.8 \pm 0.9$ \\
AM-13 & $>100$ & $27 \pm 4$ & $>100$ \\
AM-14 & $>100$ & $45 \pm 8$ & $>100$ \\
\hline
\end{tabular}

The mean value $\pm S D$ of four determinations is indicated. The structure of bombesin agonist 1 is $\left(D-T_{y} r^{6}, \beta-\mathrm{Ala}^{11}, \mathrm{Phe}^{13}, \mathrm{Nle}^{14}\right) \mathrm{BB}^{6-14}$.

BRS-3, bombesin receptor subtype-3. to NCI-H1299 cells transfected with $\mathrm{BB}_{2} \mathrm{R}$ had no effect on the basal cytosolic $\mathrm{Ca}^{2+}$ but blocked the increase in cytosolic $\mathrm{Ca}^{2+}$ caused by BA1 (Figure 2E). Addition of $30 \mu \mathrm{M}$ AM-14 had no effect of basal cytosolic $\mathrm{Ca}^{2+}$ but partially blocked the increase caused by $10 \mathrm{nM}$ BA1 (Figure 2F). Table 2 shows that ST-36 and AM-14 significantly decreased the ability of $10 \mathrm{nM}$ BA1 to elevate cytosolic $\mathrm{Ca}^{2+}$ in NCI-H1299 cells transfected with $\mathrm{BB}_{2} \mathrm{R}$. Addition of $10 \mathrm{nM}$ BA1 to NCI-H1299 cells transfected with BRS-3 increased the cytosolic $\mathrm{Ca}^{2+}$ from 170 to $194 \mathrm{nM}$ (Figure 2G). Addition of $30 \mu \mathrm{M}$ ST-36 to NCI-H1299 cells transfected with BRS-3 had no effect on the basal cytosolic $\mathrm{Ca}^{2+}$ but blocked the increase in cytosolic $\mathrm{Ca}^{2+}$ caused by BA1 (Figure 2H). Addition of $30 \mu \mathrm{M}$ AM-13 had no effect of basal cytosolic $\mathrm{Ca}^{2+}$ but partially blocked the increase caused by $10 \mathrm{nM}$ BA1 (Figure 2I). Table 2 shows that ST-36 and AM-13 significantly decreased the ability of $10 \mathrm{nM}$ BA1 to elevate cytosolic $\mathrm{Ca}^{2+}$ in NCI-H1299 cells transfected with BRS-3. The results indicate that $A M-37$ and ST-36 are antagonists for $B_{1} R, B B_{2} R$, and BRS-3. In contrast, AM-13 and AM-14 are weak antagonists for the BBR family.

The specificity of AM-37, ST-36, AM-13, and AM-14 was investigated. $10 \mathrm{nM}$ neurotensin (NT) or $5 \mu \mathrm{g} / \mathrm{ml}$ ionomycin (ION) strongly increased the cytosolic $\mathrm{Ca}^{2+}$ in NSCLC cells. AM-37 or ST-36 had no effect on the ability of NT to increase cytosolic $\mathrm{Ca}^{2+}$ in NSCLC cells. AM-13 or AM-14 had no effect on the ability of ION to increase $\mathrm{Ca}^{2+}$ in NSCLC cells. Therefore, AM-36 and ST-37 are antagonists for the BBR but not the NTR.

\section{Tyrosine Phosphorylation}

The ability of the small molecules to impair EGFR transactivation was investigated. Previously, we found that the $B_{1} R$ and BRS-3 regulate EGFR tyrosine phosphorylation $(13,16)$. Figure 3 shows that addition of 100 nM BA1 to NCI-H1299 cells transfected with $\mathrm{BB}_{2} \mathrm{R}$ increased significantly the EGFR tyrosine phosphorylation to $326 \%$. If the cells were pretreated with $10 \mu \mathrm{M}$ AM-37 or ST-36, addition of BA1 had little effect. In contrast, if the cells were treated with $10 \mu \mathrm{M}$ AM-13, BA1 increased strongly EGFR tyrosine phosphorylation. Similarly, BA1 addition to NCI-H1299 cells transfected with $\mathrm{BB}_{2} \mathrm{R}$ increased ERK tyrosine phosphorylation to $277 \%$. This increase in ERK tyrosine phosphorylation was decreased significantly in the cells pretreated with AM-37 or ST-36 but not AM-13. Similarly, AM-14 had little effect on EGFR or ERK tyrosine phosphorylation (data not shown). The results indicate that AM-37 and ST-36 antagonize the ability of the $\mathrm{BB}_{2} \mathrm{R}$ to regulate tyrosine phosphorylation of the EGFR and ERK. Similar transactivation results were obtained for NSCLC cells transfected with $\mathrm{BB}_{1} \mathrm{R}$ or BRS-3 (data not shown).

\section{Proliferation}

The ability of the small molecules to inhibit lung cancer proliferation was investigated. AM-37 inhibited NCI-H1299 proliferation in a dose-dependent manner. Figure 4 shows that AM-37 had little effect at $3 \mu \mathrm{M}$ but strongly inhibited proliferation at $30 \mu \mathrm{M}$. The $\mathrm{IC}_{50}$ for AM-37 was $16 \mu \mathrm{M}$. Similarly, ST-36 had an $\mathrm{IC}_{50}$ of $22 \mu \mathrm{M}$, whereas AM-14 was less potent $\left(\mathrm{IC}_{50}>50 \mu \mathrm{M}\right)$. 

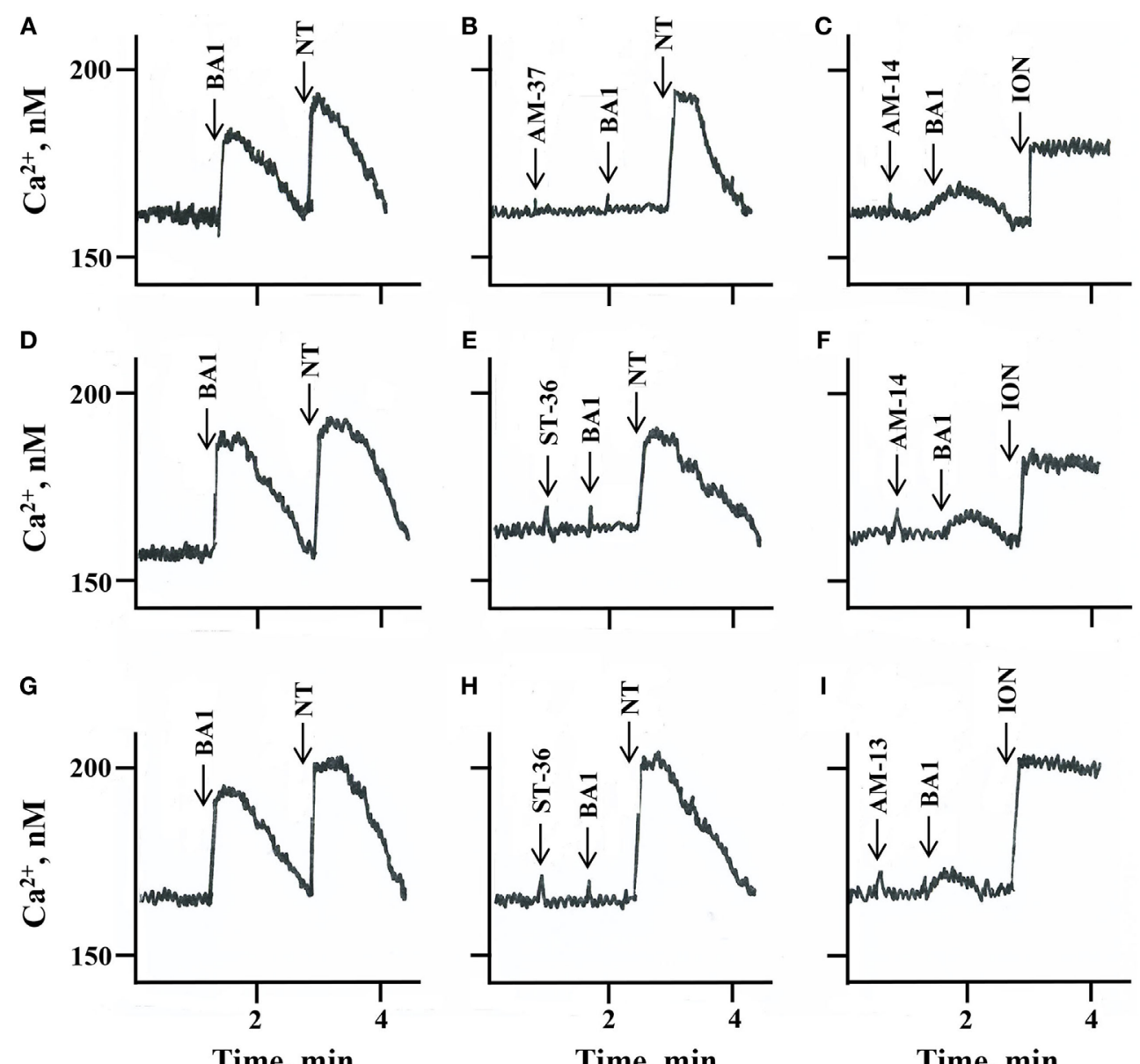

Time, $\min$

Time, $\min$

Time, $\min$

FIGURE 2 | Cytosolic $\mathrm{Ca}^{2+}$. The ability of (A) $10 \mathrm{nM}$ bombesin agonist 1 (BA) 1 and $10 \mathrm{nM}$ neurotensin (NT), (B) $30 \mu \mathrm{M}$ AM-37 followed by $10 \mathrm{nM}$ BA1 and $10 \mathrm{nM}$ NT, and (C) $30 \mu \mathrm{M}$ AM-14 followed by $10 \mathrm{nM}$ BA1 and $5 \mu \mathrm{g} / \mathrm{ml}$ ionomycin (ION) to increase cytosolic $\mathrm{Ca}^{2+}$ was determined as a function of time after the addition to $\mathrm{NCl}-\mathrm{H} 1299$ cells transfected with BB, R. The ability of (D) $10 \mathrm{nM}$ BA1 and $10 \mathrm{nM}$ NT, (E) $30 \mu \mathrm{M}$ ST-36 followed by $10 \mathrm{nM}$ BA1 and $10 \mathrm{nM}$ NT, and (F) $30 \mu \mathrm{M}$ AM-14 followed by 10 nM $\mathrm{BA} 1$ and $5 \mathrm{\mu g} / \mathrm{ml} \mathrm{ION}$ to increase cytosolic $\mathrm{Ca}^{2+}$ was determined as a function of time after the addition to $\mathrm{NCl}-\mathrm{H} 1299$ cells transfected with $\mathrm{BB}_{2} \mathrm{R}$. The ability of (G) $10 \mathrm{nM}$

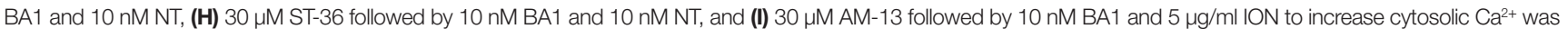
determined as a function of time after the addition to $\mathrm{NCl}-\mathrm{H} 1299$ cells transfected with bombesin receptor subtype-3. This experiment is representative of three others.

TABLE 2 | Increases in cytosolic $\mathrm{Ca}^{2+}$ using human lung cancer cells transfected with bombesin receptors.

\begin{tabular}{lccc}
\hline Addition & \multicolumn{3}{c}{ Increase in cytosolic $\mathbf{C a}^{2+}, \mathbf{n M}$} \\
\cline { 2 - 4 } & $\mathbf{B B}_{1} \mathbf{R}$ & $\mathbf{B B}_{2} \mathbf{R}$ & BRS-3 \\
\hline $\mathrm{BA1}, 10 \mathrm{nM}$ & $18.5 \pm 1.1$ & $26.3 \pm 1.7$ & $24.4 \pm 2.3$ \\
$\mathrm{BA1}+\mathrm{AM}-37,30 \mu \mathrm{M}$ & $1 \pm 0.6^{\mathrm{a}}$ & $0^{\mathrm{a}}$ & $0^{\mathrm{a}}$ \\
$\mathrm{BA1}+\mathrm{ST}-36,30 \mu \mathrm{M}$ & $0^{\mathrm{a}}$ & $0^{\mathrm{a}}$ & $0^{\mathrm{a}}$ \\
$\mathrm{BA1}+\mathrm{AM}-13,30 \mu \mathrm{M}$ & $7 \pm 0.8^{\mathrm{a}}$ & $5 \pm 0.6^{\mathrm{a}}$ & $2 \pm 0.3^{\mathrm{a}}$ \\
$\mathrm{BA1}+\mathrm{AM}-14,30 \mu \mathrm{M}$ & $6+0.6^{\mathrm{a}}$ & $6+0.5^{\mathrm{a}}$ & $3+0.4^{\mathrm{a}}$
\end{tabular}

The initial increase in the cytosolic $\mathrm{Ca}^{2+}$ after addition of $\mathrm{BA} 1$ to lung cancer cells containing $B B_{1} R, B B_{2} R$, or BRS-3 is indicated. Addition of small molecules significantly inhibited ( $p<0.01$; $^{a}$ by ANOVA) the ability of BA1 to increase cytosolic $\mathrm{Ca}^{2+}$. This experiment is representative of three others.

BRS-3, bombesin receptor subtype-3, BA1, bombesin agonist 1 .

The specificity of the small molecules was investigated. Table 3 shows that AM-37, ST-36, AM-13, and AM-14 (50 $\mu \mathrm{M})$ inhibited significantly the proliferation of NCI-H727 cells, which have
mRNA for $\mathrm{BB}_{1} \mathrm{R}, \mathrm{BB}_{2} \mathrm{R}$, and BRS-3. In contrast, $\mathrm{AM}-37$, ST-36, AM-13, and AM-14 had little effect on NCI-H1975 cells, which lack $\mathrm{BB}_{1} \mathrm{R}, \mathrm{BB}_{2} \mathrm{R}$, and $\mathrm{BRS}-3$. These results indicate that the $\mathrm{BBR}$ is essential for AM-37, ST-36, AM-13, or AM-14 to inhibit cancer cellular proliferation.

\section{DISCUSSION}

While NSCLC patients are traditionally treated with combination chemotherapy, the 5-year survival rate is only $16 \%$ (17). Some NSCLC patients (13\%) have L858R EGFR mutations, and these patients respond to TKI such as gefitinib or erlotinib; however, secondary EGFR mutations can occur such as T790M resulting in TKI resistance (18). Numerous GPCR are expressed in lung cancer cell lines and biopsy specimens. $\mathrm{BB}_{2} \mathrm{R}$ mRNA is expressed in $46-67 \%$ of the lung cancer cell lines examined (19). $\mathrm{BB}_{1} \mathrm{R}$ mRNA is present in $81 \%$ of the NSCLC cell lines examined (20). Using autoradiographic techniques, 

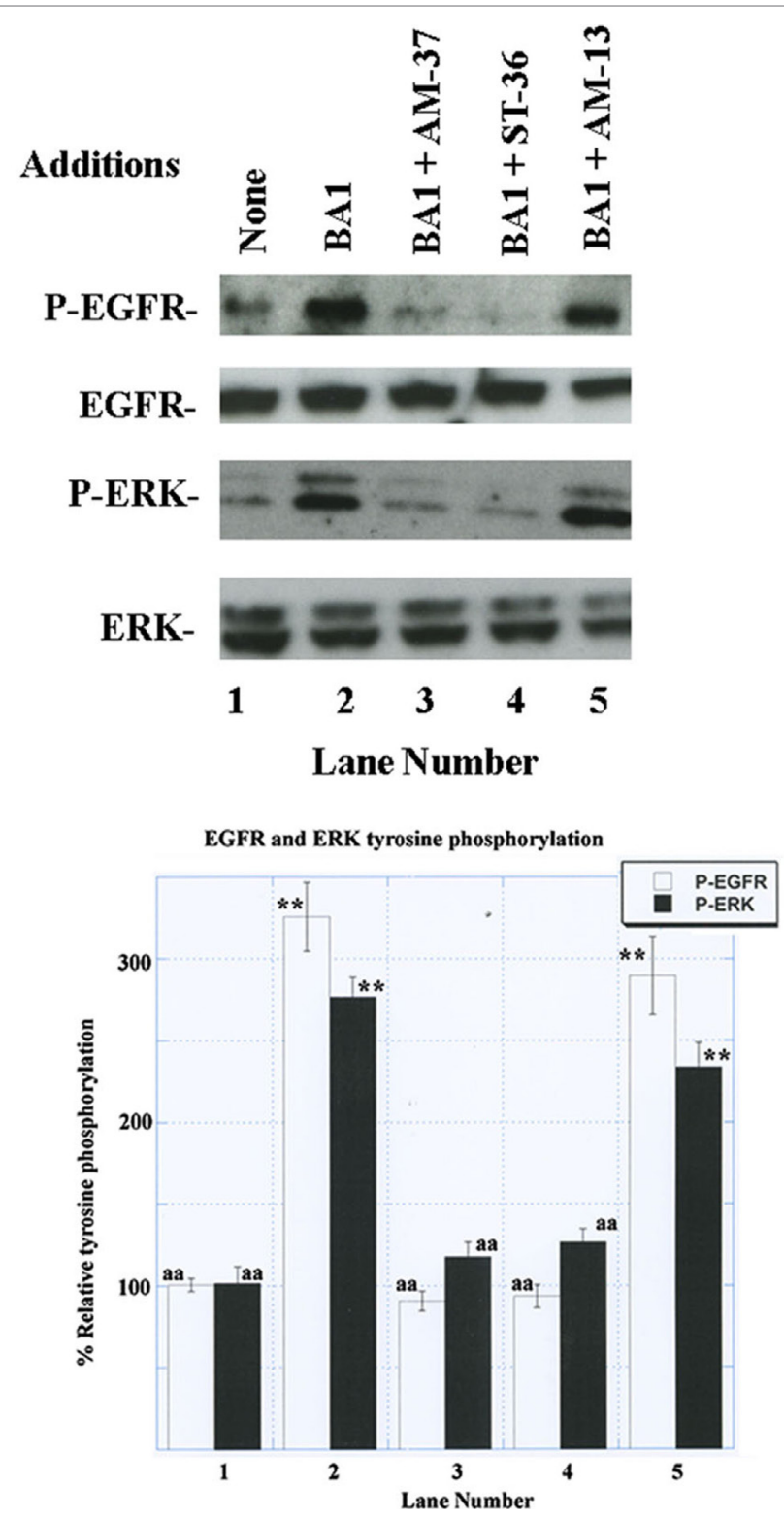

FIGURE 3 | Western blot. (Top) The ability of $100 \mathrm{nM}$ bombesin agonist (BA)1 to increase EGFR and ERK tyrosine phosphorylation was investigated using NCl-H1299 cells transfected with $\mathrm{BB}_{2} \mathrm{R}$ in the presence of $10 \mu \mathrm{M}$ AM-37, $10 \mu \mathrm{M}$ ST-36, and $10 \mu \mathrm{M}$ AM-13. (Bottom) BA1 or BA1 plus AM-13 increased significantly EGFR and ERK tyrosine phosphorylation relative to the control, whereas total ERK and EGFR were unaltered; $p<0.01$; ** by ANOVA. The control, BA1 + AM-37, and BA1 + ST-36 were significantly reduced relative to BA1; $p<0.01$, aa by ANOVA. The experiment is representative of three others.

BRS-3 binding sites were detected in $40 \%$ of the lung cancer biopsy specimens examined (21). The EGFR is abundant on NSCLC (approximately 100,000 EGFR/cell), whereas BBR are present on most native NSCLC cells (approximately 2,000 BBR/ cell) (22).

Addition of GRP to NSCLC cells causes transactivation of the EGFR (23). The effects of GRP on NSCLC tyrosine phosphorylation of the EGFR are impaired by gefitinib, a TKI, and PD176252, a peptoid $\mathrm{BB}_{2} \mathrm{R}$ antagonist. Because the ERK and EGFR tyrosine phosphorylation caused by GRP was impaired by marimastat, GM6001 and antibodies to TGF $\alpha$, matrix metalloproteases may regulate the cellular shedding of TGF $\alpha$ from NSCLC cells. The TGF $\alpha$ may then bind to the EGFR causing its tyrosine phosphorylation. The results indicate that the $\mathrm{BB}_{2} \mathrm{R}$ regulates EGFR transactivation in NSCLC cells.

The $\mathrm{BB}_{1} \mathrm{R}$ regulates EGFR transactivation (16). The increase in EGFR and ERK tyrosine phosphorylation caused by NMB addition to NSCLC cells was impaired by PD168368, a $\mathrm{BB}_{1} \mathrm{R}$ peptoid antagonist, as well as gefitinib. The increase in EGFR tyrosine phosphorylation caused by $\mathrm{NMB}$ was impaired by $\mathrm{N}$-acetyl cysteine (NAC), an antioxidant, or tiron, a superoxide scavenger. NMB increased reactive oxygen species (ROS) in NSCLC cells, and the increase was inhibited by Tiron. It remains to be determined if the ROS impair protein tyrosine phosphatases in NSCLC cells, which remove phosphate from the P-EGFR. Activation of BRS-3 with BA1 increased EGFR and ERK tyrosine phosphorylation (13). The increase in EGFR tyrosine phosphorylation caused by BA1 is impaired by NAC, tiron, and diphenyleneiodonium, an inhibitor of NADPH oxidase enzymes.

ML-18 is a small molecule that prefers BRS-3 relative to $\mathrm{BB}_{1} \mathrm{R}$ or $\mathrm{BB}_{2} \mathrm{R}$ (24). ML-18, an S-enantiomer, inhibits ${ }^{125} \mathrm{I}-\mathrm{BA} 1$ binding to $\mathrm{BRS}-3, \mathrm{BB}_{2} \mathrm{R}$, and $\mathrm{BB}_{1} \mathrm{R}$ with $\mathrm{IC}_{50}$ values of $4.8,16$, and $>100 \mu \mathrm{M}$, respectively, whereas the R-enantiomer EMY-98 is inactive. ML-18 is a BRS-3 antagonist, which inhibits the ability of BA1 to increase cytosolic $\mathrm{Ca}^{2+}$, increase ERK and EGFR tyrosine phosphorylation (24). Also, ML-18 inhibited NSCLC growth and increased the cytotoxicity of gefitinib. $\mathrm{His}^{107}$ is important for BRS-3 to bind antagonists with high affinity (25). Tyr ${ }^{101}$ of the $\mathrm{BB}_{2} \mathrm{R}$ is important for binding of non-peptide antagonists (26). Similarly, this Tyr is conserved in the $\mathrm{BB}_{1} \mathrm{R}$ and $\mathrm{BRS}-3$. It remains to be determined if this Tyr is essential for binding of $A M-37$ to the $B_{1} R, B_{2} R$, or BRS-3. ST-36, which is an S-enantiomer, inhibited specific ${ }^{125} \mathrm{I}-\mathrm{BA} 1$ binding to $\mathrm{BB}_{1} \mathrm{R}, \mathrm{BB}_{2} \mathrm{R}$, and $\mathrm{BRS}-3$ with $\mathrm{IC}_{50}$ values of $7.9,6.9$, and $10.8 \mu \mathrm{M}$, respectively. It is surprising that AM-37, which is the R-enantiomer, binds with slightly higher affinity to BBR than does ST-36. Previously, the $\mathrm{BB}_{1} \mathrm{R}$ was found to prefer $\mathrm{PD} 168,368$, which is an S-isomer, relative to the R-isomer (27).

(D-Arg ${ }^{1}, \mathrm{D}$-Trp $\mathrm{T}^{5,7,9}, \mathrm{Leu}^{11}$ )substance P (SP) is an inhibitor of signal transduction and growth of SCLC cells (28). (D-Arg ${ }^{1}$, $\mathrm{D}-\operatorname{Tr}^{5,7,9}$, Leu $\left.{ }^{11}\right) \mathrm{SP}$ impaired the ability of $\mathrm{BB}$, vasopressin, or bradykinin to increase cytosolic $\mathrm{Ca}^{2+}$ and ERK activity. (D-Arg $\left.{ }^{1}, \mathrm{D}-\operatorname{Trp}^{5,7,9}, \mathrm{Leu}^{11}\right) \mathrm{SP}$ decreased SCLC growth in vitro, and $\left(\mathrm{D}-\mathrm{Arg}^{1}, \mathrm{D}-\operatorname{Trp}^{5,7,9}, \mathrm{Leu}^{11}\right) \mathrm{SP}$ has a unique tertiary structure in with two type IV non-standard turns, which juxtapose the $\mathrm{N}$ - and C-terminal adjacent to one another (29). Due to this unique structure (D-Arg $\left.{ }^{1}, \mathrm{D}-\operatorname{Trp}^{5,7,9}, \mathrm{Leu}^{11}\right) \mathrm{SP}$ may be able to interact with multiple GPCR. In contrast, AM-37 and ST-36 are small molecules that have a different structure from that of (D-Arg ${ }^{1}, \mathrm{D}-\operatorname{Trp}^{5,7,9}$, Leu $\left.^{11}\right)$ SP.

AM-37 and ST-36 inhibited the proliferation of NSCLC cells such as NCI-H1299 and H727, which have $\mathrm{BB}_{1} \mathrm{R}, \mathrm{BB}_{2} \mathrm{R}$, or BRS-3. 


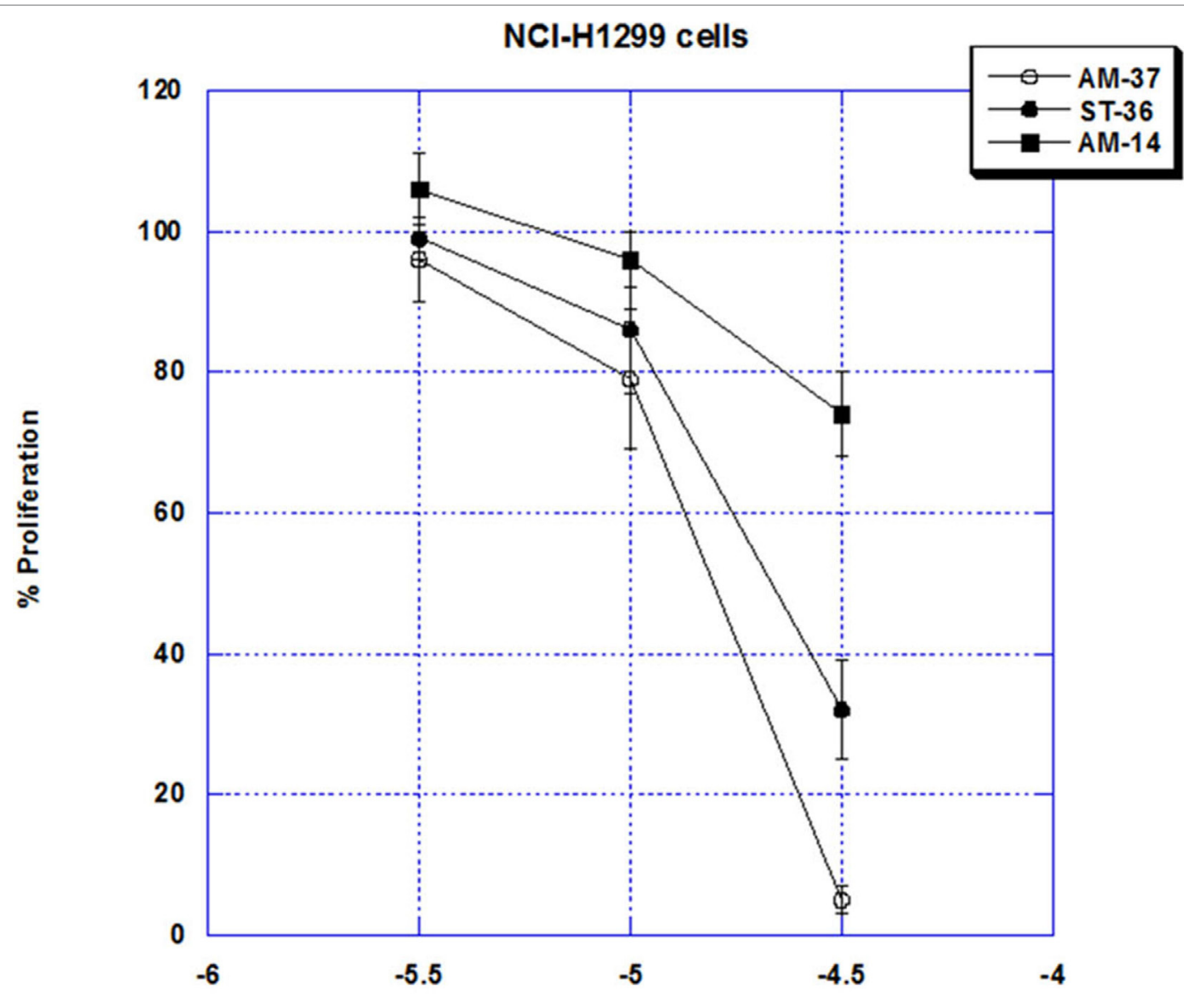

[Ligand], Log $M$

FIGURE 4 | MTT assay. The ability of varying doses of AM-37 (o), ST-36 (•), and AM-14 (घ), to inhibit the proliferation of NCl-H1299 cells is shown. The mean value $\pm \mathrm{SD}$ of eight determinations is indicated. This experiment is representative of two others.

TABLE 3 | MTT proliferation assay using human lung cancer cell lines.

\begin{tabular}{lcr}
\hline Addition & \multicolumn{2}{c}{$\%$ proliferation } \\
\cline { 2 - 3 } & NCI-H727 & NCl-H1975 \\
\hline None & $100 \pm 5$ & $100 \pm 6$ \\
AM-37, $50 \mu \mathrm{M}$ & $13 \pm 1^{\text {aa }}$ & $103 \pm 5$ \\
ST-36, $50 \mu \mathrm{M}$ & $30 \pm 3^{\text {aa }}$ & $95 \pm 5$ \\
AM-13, $50 \mu \mathrm{M}$ & $67 \pm 4^{\mathrm{a}}$ & $89 \pm 5$ \\
AM-14, 50 $\mu \mathrm{M}$ & $64 \pm 3^{\mathrm{a}}$ & $88 \pm 6$
\end{tabular}

The ability of AM-37, ST-36, AM-13, and AM-14 to inhibit non-small cell lung cancer growth was determined using $\mathrm{NCl}-\mathrm{H} 727$, which express $B B_{1} R, B B_{2} R$, and bombesin receptor subtype-3 and $H 1975$ cells, which do not express BBR. The mean value $\pm S D$ of eight determinations is indicated. This experiment is representative of two others; ${ }^{a} p<0.05,{ }^{a a} p<0.01$, relative to no additions by ANOVA. Using a test for normality, the data points had a Gaussian distribution.

In contrast, AM-37 and ST-36 have little effect on NSCLC cell line NCI-H1975, which lacks $\mathrm{BB}_{1} \mathrm{R}, \mathrm{BB}_{2} \mathrm{R}$, and $\mathrm{BRS}-3$. It remains to be determined if AM-37 or ST-36 are synergistic with gefitinib at inhibiting the growth of NSCLC. A goal is to identify
GPCR antagonists, which potentiate the action of TKI in NSCLC patients.

\section{CONCLUSION}

AM-37 and ST-36 are small molecules, which bind to the $\mathrm{BB}_{1} \mathrm{R}$, $\mathrm{BB}_{2} \mathrm{R}$, and BRS-3. Because AM-37 and ST-36 inhibit the ability of BA1 to increase cytosolic $\mathrm{Ca}^{2+}$ as well as increase EGFR and ERK tyrosine phosphorylation, they function as $\mathrm{BB}_{1} \mathrm{R}, \mathrm{BB}_{2} \mathrm{R}$, and BRS-3 antagonists. A particular advantage of AM-37 and ST-36 is that they will inhibit the growth of NSCLC cells if they have $\mathrm{BB}_{1} \mathrm{R}, \mathrm{BB}_{2} \mathrm{R}$, or BRS-3.

\section{AUTHOR CONTRIBUTIONS}

TM and SM were responsible for the receptor binding studies. TM and NT were responsible for the cell culture and calcium experiments. TM, PM, and IR-A were responsible for the transactivation and growth experiments. ML was responsible for the synthesis of the small molecules. TM and RJ were responsible for the writing of the manuscript. 


\section{ACKNOWLEDGMENTS}

The authors thank Drs. M. Nicklaus, E. Lacivita, D. Venzon, and M. Peach for helpful discussions.

\section{REFERENCES}

1. Moreno P, Ramos-Alvarez I, Moody TW, Jensen RT. Bombesin related peptides/receptors and their promising therapeutic roles in cancer imaging, targeting and treatment. Expert Opin Ther Targets (2016) 20:1055-73. doi:10.1517/14728222.2016.1164694

2. Ramos-Alvarez I, Moreno P, Mantey SA, Nakamura T, Nuche-Berenguer B, Moody TW, et al. Insights into bombesin receptors and ligands: highlighting recent advances. Peptides (2015) 72:128-44. doi:10.1016/j.peptides. 2015.04.026

3. Mantey SA, Weber HC, Sainz E, Akeson M, Ryan RR, Pradhan TK, et al. Discovery of a high affinity radioligand for the human orphan receptor, bombesin receptor subtype3, which demonstrates it has a unique pharmacology compared to other mammalin bombesin receptors. J Biol Chem (1997) 272:26062-71. doi:10.1074/jbc.272.41.26062

4. Majumdar ID, Weber HC. Appetite-modifying effects of bombesin receptor subtype-3 agonists. Handb Exp Pharmacol (2012) 209:405-32. doi:10.1007/ 978-3-642-24716-3_19

5. Moody TW, Merali Z. Bombesin-like peptides and associated receptors within the brain: distribution and behavioral implications. Peptides (2004) 25:511-20. doi:10.1016/j.peptides.2004.02.012

6. Moody TW, Pert CB, Gazdar AF, Carney DN, Minna JD. High levels of intracellular bombesin characterize human small-cell lung carcinoma. Science (1981) 214:1246-8. doi:10.1126/science.6272398

7. Wood SM, Wood JR, Ghatei MA, Lee YC, O'Shaughnessy D, Bloom SR. Bombesin, somatostatin and neurotensin-like immunoreactivity in bronchial carcinoma. J Clin Endocrinol Metab (1981) 53:1310-2. doi:10.1210/ jcem-53-6-1310

8. Cuttitta F, Carney DN, Mulshine J, Moody TW, Fedorko J, Fischler A, et al. Bombesin-like peptides can function as autocrine growth factors in human small cell lung cancer. Nature (1985) 316:823-6. doi:10.1038/316823a0

9. Giaccone G, Battey J, Gazdar AF, Oie H, Draoui M, Moody TW. Neuromedin B is present in lung cancer cell lines. Cancer Res (1993) 52:2732s-6s.

10. Moody TW, Moreno P, Jensen RT. Neuropeptides as lung cancer growth factors. Peptides (2015) 72:106-11. doi:10.1016/j.peptides.2015.03.018

11. Moody TW, Nuche-Berenguer B, Nakamura T, Jensen RT. EGFR transactivation by peptide $\mathrm{G}$ protein-coupled receptors in cancer. Curr Drug Targets (2016) 17:520-8. doi:10.2174/1389450116666150107153609

12. Jensen RT, Battey JF, Spindel ER, Benya RV. Mammalian bombesin receptors: nomenclature, distribution, pharmacology, signaling and functions in normal and disease states. Pharmacol Rev (2008) 60:1-42. doi:10.1124/pr.107.07108

13. Moody TW, Sancho V, Di Florio A, Nuche-Berenguer B, Mantey SA, Jensen RT. Bombesin receptor subtype-3 agonists stimulate the growth of lung cancer cells and increase EGF receptor tyrosine phosphorylation. Peptides (2011) 32:1677-84. doi:10.1016/j.peptides.2011.06.011

14. Lacivita E, Schepetkin IA, Stama ML, Kirpotina LN, Colabufo NA, Perrone R, et al. Novel 3-(1H-indoyl-3-yl)-2-[3-(4-methoxyphenyl)ureido] propanamides as selective agonist of human formyl-peptide receptor2. Bioorg Med Chem (2015) 23:3913-24. doi:10.1016/j.bmc.2014.12.007

15. Chang Y, Prusoff WH. Relationship between the inhibition constant (KI) and the concentration of inhibitor which causes 50\% inhibition (I50) of an enzymatic reaction. Biochem Pharmacol (1973) 22:3099-108. doi:10.1016/ 0006-2952(73)90196-2

16. Moody TW, Berna MJ, Mantey S, Sancho V, Ridnour L, Wink DA, et al. Neuromedin B receptors regulate EGF receptor tyrosine phosphorylation in lung cancer cells. Eur J Pharmacol (2010) 637:38-45. doi:10.1016/j. ejphar.2010.03.057

17. Kaufman J, Horn L, Carbone D. Molecular biology of lung cancer. In: DeVita W Jr, Lawrence T, Rosenberg SA, editors. Cancer: Principles and

\section{FUNDING}

This research was supported by the intramural programs of the NCI and NIDDK of the NIH.

Practice of Oncology. Philadelphia: Lippincott, Williams \& Wilkens (2011). p. 789-98.

18. Lopes GL, Vattimo EF, Castro Junior GD. Identifying activating mutations in the EGFR gene: prognostic and therapeutic implications in non-small cell lung cancer. JBras Pneumol (2015) 41:365-75. doi:10.1590/S180637132015000004531

19. Corjay M, Dobrzanski DJ, Way JM, Viallet J, Shapira H, Worland P, et al. Two distinct bombesin receptor subtypes are expressed and functional in human lung carcinoma cells. J Biol Chem (1991) 266:18771-9.

20. Siegfried JM, Krishnamachary N, Gaither Davis A, Gubish C, Hunt JD, Shriver SP. Evidence for autocrine actions of neuromedin B and gastrinreleasing peptide in non-small cell lung cancer. Pulm Pharmacol Ther (1999) 12:291-302. doi:10.1006/pupt.1999.0210

21. Reubi JC, Wenger S, Schmuckli-Mauer J, Schaer JC, Gugger M. Bombesin receptor subtypes in human cancers: detection with the universal radioligand ${ }^{125} \mathrm{I}-\left[\mathrm{D}-\mathrm{Tyr}^{6}, \beta-\mathrm{Ala}^{11}, \mathrm{Phe}^{13}, \mathrm{Nle}^{14}\right]$ bombesin(6-14). Clin Cancer Res (2002) $8: 11139-46$.

22. Moody TW, Lee M, Kris RM, Bellot F, Bepler G, Oie H, et al. Lung carcinoid cell lines have bombesin-like peptides and EGF receptors. J Cell Biochem (1990) 43:139-47. doi:10.1002/jcb.240430205

23. Thomas SM, Grandis JR, Wentzel AL, Gooding WE, Lui VWY, Siegfried JM. Gastrin-releasing peptide receptor mediates activation of the epidermal growth factor receptor in lung cancer cells. Neoplasia (2006) 7:426-31. doi:10.1593/neo.04454

24. Moody TW, Mantey SA, Moreno P, Nakamura T, Lacivita E, Leopoldo M, et al. ML-18 is a non-peptide bombesin receptor subtype-3 antagonist which inhibits lung cancer growth. Peptides (2015) 64:55-61. doi:10.1016/j. peptides.2014.12.005

25. Nakamura T, Ramos-Alvarez I, Iordanskaia T, Moreno P, Mantey SA, Jensen RT. Molecular basis for high affinity and selectivity of peptide antagonists, Bantag-1, for the orphan BB3 receptor. Biochem Pharmacol (2016) 115:64-76. doi:10.1016/j.bcp.2016.06.013

26. Carrieri A, Lacivita E, Danilo Belviso B, Caliandro R, Mastrorilli P, Gallo V, et al. Structural determinants in the binding of BB2 receptor ligands: in silico, $\mathrm{x}$-ray and NMR studies in PD176252 analogues. Curr Top Med Chem (2017) 17:1599-610. doi:10.2174/1568026617666161104102459

27. Ashwood V, Brownhill V, Higginbottom M, Horwell D, Hughes J, Lewthwaite A, et al. PD176252-the first high affinity non-peptide gastrin-releasing peptide (BB2) receptor antagonist. Bioorg Med Chem Lett (1996) 8:2589-94. doi:10.1016/S0960-894X(98)00462-4

28. Seckl MJ, Higgins T, Widner F, Rozengurt E. [D-Arg1, D-Trp5,7,9, Leu11] substance $\mathrm{P}$, A novel potent inhibitor of signal transduction and growth in vitro and in vivo in small cell lung cancer cells. Cancer Res (1997) 57:51-4

29. Jeire DA, Kumar M, Hu WS, Sinnett-Smith J, Rozengurt EA. The lipidassociated 3D structure of SPA, a broad-spectrum neuropeptide antagonist with anticancer properties. Biophys J (2006) 91:4478-89. doi:10.1529/ biophysj.106.089292

Conflict of Interest Statement: The authors declare that the research was conducted in the absence of any commercial or financial relationships that could be construed as potential conflicts of interest.

Copyright (C) 2017 Moody, Tashakkori, Mantey, Moreno, Ramos-Alvarez, Leopoldo and Jensen. This is an open-access article distributed under the terms of the Creative Commons Attribution License (CC BY). The use, distribution or reproduction in other forums is permitted, provided the original author(s) or licensor are credited and that the original publication in this journal is cited, in accordance with accepted academic practice. No use, distribution or reproduction is permitted which does not comply with these terms. 